\title{
Effects of Humic Acid and Crop Residues on Soil and Wheat Nitrogen Contents
}

\author{
Kashif Akhtar ${ }^{1}$, Syed Noor Muhammad Shah ${ }^{2,3}$, Amjad Ali4*, Sajjad Zaheer ${ }^{5}$, \\ Fazli Wahid", Ahmad Khan', Mohib Shah7 , Shahida Bibi" , Abdul Majid9 \\ ${ }^{1}$ Department of Agronomy, Amir Muhammad Khan Campus Mardan, University of Agriculture, Peshawar, \\ Pakistan \\ ${ }^{2}$ Department of Horticulture, Faculty of Agriculture, Gomal University, D.I. Khan, Pakistan \\ ${ }^{3}$ College of Horticulture, Northwest A\&F University, Yangling, China \\ ${ }^{4}$ College of Natural Resources and Environment, Northwest A\&F University, Yangling, China \\ ${ }^{5}$ Department of Agronomy, Faculty of Crop Production Sciences, University of Agriculture, Peshawar, Pakistan \\ ${ }^{6}$ Soil and Environmental Sciences, University of Agriculture, Peshawar, Pakistan \\ ${ }^{7}$ Department of Botany, Abdul Wali Khan University, Mardan, Pakistan \\ ${ }^{8}$ Department of Weed Science, University of Agriculture, Peshawar, Pakistan \\ ${ }^{9}$ Department of Agriculture Chemistry, Faculty of Agriculture, Gomal University D.I. Khan, Pakistan \\ Email: amjadali@aup.edu.pk
}

Received 14 February 2014; revised 18 March 2014; accepted 28 March 2014

Copyright (C) 2014 by authors and Scientific Research Publishing Inc.

This work is licensed under the Creative Commons Attribution International License (CC BY).

http://creativecommons.org/licenses/by/4.0/

\section{c) (i) Open Access}

\section{Abstract}

This study was conducted with the aim of finding humic acid and crop residues effects on soil and wheat nitrogen at New Development Farm, University of Agriculture, Peshawar, Pakistan during winter 2009-2010. The experiment was laid out in RCB design having four replications. Different levels (1, 1.5, 2 and $\left.2.5 \mathrm{~kg} \mathrm{ha}^{-1}\right)$ of Humic acid were applied at sowing time. Mungbean (5 tons ha-1), wheat straw (10 tons ha-1) and mungbean ( 2.5 tons ha-1) + wheat straw ( 5 tons ha- ${ }^{-1}$ ) were incorporated 30 days before sowing. Our results showed higher mineral and total nitrogen $(7.32$ and 0.43 , respectively) $\mathrm{mg} \mathrm{kg}^{-1}$ in soil and also higher nitrogen in stem, leaves and grains $(2.3,4.6$ and 21.1 , respectively) $\mathrm{mg} \mathrm{kg}^{-1}$ at maturity in those plots in which $2.5 \mathrm{~kg} \mathrm{ha}^{-1}$ of humic acid was applied. Higher mineral and total nitrogen (7.04 and 0.5 , respectively) $\mathrm{mg} \mathrm{kg}^{-1}$ in soil and also higher nitrogen in leaves (5.5) $\mathrm{mg} \mathrm{kg}^{-1}$ at pre-anthesis, while at maturity stage in stem, leaves and grain $(5.5,2.1,4.2$ and 20.8$) \mathrm{g} \mathrm{kg}^{-1}$ was recorded in those plots in which 5 tons ha-1 mung bean was incorporated. Our experimental results suggest the use of 5 tons ha-1 of mungbean residues with 2.5 $\mathrm{kg} \mathrm{ha}^{-1}$ of humic acid to improve soil fertility availability of more nitrogen in wheat plants to increase the crop yield and grains quality.

"Corresponding author. 


\section{Keywords}

\section{Anthesis; Grain; Maturity; Soil Fertility; Straw; Mung Bean}

\section{Introduction}

Wheat (Triticum aestivum L.) belongs to the family Poaceae. It is an annual Rabi, self pollinated and long day plant grown as a winter crop in Pakistan. The demand for wheat production is increasing with increasing population of Pakistan day by day. The present production of wheat is not sufficient to meet the requirement of population. So to meet the demand for the wheat production, either bringing more area under cultivation or increasing yield per unit area will be required. The cultivated wheat area was 9.04 million ha with total production of 23.86 million tons with average yield of $2639 \mathrm{~kg} \mathrm{ha}^{-1}$ during 2009-10 in Pakistan [1]. Wheat is an exhaustive crop, which not only depletes soil fertility but also degrades soil physical properties. The soil of NWFP is deficient in organic matter, nitrogen, phosphorous and zinc [2]. To overcome the problem of nutrient deficiency and increase wheat yield, the farmers usually applied chemical fertilizers. However, small farmers cannot afford optimum chemical fertilizers due to high prices, which resulted in low production [3]. But integrated use of chemical and organic fertilizer/manures can play an important role in sustained soil fertility and crop productivity [4]. However, mineral nitrogenous fertilizers are the rich source of nitrogen as a plant nutrient but it also contributed to environmental hazards in various ways [5]. On the other hand, manures and residues are bulky in nature and generally comprise of cellulose $(15 \%-60 \%)$, hemi cellulose $(10 \%-30 \%)$ water soluble fraction $(5 \%-30 \%)$, alcohol soluble fraction (fats, oil, waxes, resins and pigments) and protein containing $\mathrm{N}$ and $\mathrm{S}$ mineral constituent. Humic acid (HA) is a natural product, which is abundant in our lignitic coal and is applied in agriculture and industry [6]. Humic acid (HA), which contains organic C (51\% - 57\%), N (4\% - 6\%) and P (0.2\% - 1.0\%), can improve crop yield due to its capability of supplying $\mathrm{N}$ and $\mathrm{P}$ to the plants. But usually $1-2 \mathrm{~kg} \mathrm{ha}^{-1} \mathrm{HA}$ added to the crop as fertilizer [7] [8] which will hardly supply 0.04 to $0.08 \mathrm{~kg} \mathrm{~N}$ and $0.001 \mathrm{~kg} \mathrm{P} \mathrm{ha}^{-1}$ to soil. This amount is far below the overall nutrients requirement of agricultural crops [7]. HA improved the physicochemical and biological properties of the soils [8]. Bama et al. [9] reported a linear trend in the release of $\mathrm{N}, \mathrm{P}$ and $\mathrm{K}$ in the application of HA. They have also reported that the release of $\mathrm{N}$ was significant up to $20 \mathrm{~kg}$ of HA ha ${ }^{-1}$, whereas for $\mathrm{P}$ and $\mathrm{K}$ it extended up to $40 \mathrm{~kg} \mathrm{ha}^{-1}$. Further, they have observed the released of $\mathrm{N}$ and $\mathrm{P}$ for a longer period of 60 days, while $\mathrm{K}$ released for 45 days. Crop residues are good sources of plant nutrients and are important components for the stability of agricultural ecosystems. In areas where mechanical harvesting is practiced, a large quantity of crop residues are left in the field, which can be recycled for nutrient supply. About $25 \%$ of nitrogen $(\mathrm{N})$ and phosphorus $(\mathrm{P}), 50 \%$ of sulfur $(\mathrm{S})$, and $75 \%$ of potassium $(\mathrm{K})$ uptake by cereal crops are retained in crop residues, making them valuable nutrient sources. Both rice and wheat are exhaustive feeders, and the double cropping system is heavily depleting the soil of its nutrient content. A rice-wheat sequence that yields 7 tons ha ${ }^{-1}$ of rice and 4 tons ha ${ }^{-1}$ of wheat removes more than $300 \mathrm{~kg} \mathrm{~N}, 30 \mathrm{~kg} \mathrm{P}$, and $300 \mathrm{~kg} \mathrm{~K} \mathrm{ha}^{-1}$ from the soil [10]. There are very limited literatures available on the combine use of humic acid and crop residues. Therefore, the present research was designed to study the humic acid and crop residues effects on soil and wheat nitrogen content.

\section{Materials and Methods}

The experiment was performed at New Developmental Farm, University of Agriculture, Peshawar during winter 2009-10. The experiment was layout in randomized complete block (RCB) design, replicated four times, with plot size $5 \mathrm{~m} \times 3 \mathrm{~m}$. Wheat (cv. Pirsabak-2005) seeds were sown at proper moisture condition with $30 \mathrm{~cm}$ row to row distance. The total and mineral Nitrogen in the soil was $0.2 \mathrm{~g} \mathrm{~kg}^{-1}$ and $6.0 \mathrm{mg} \mathrm{kg}^{-1}$ respectively.

The treatments were;

$\mathrm{T}_{1}$ : Control

$\mathrm{T}_{2}$ : Humic Acid $\left(1 \mathrm{~kg} \mathrm{ha}^{-1}\right)+$ Mungbeans residue $\left(5\right.$ tons ha $\left.{ }^{-1}\right)$

$\mathrm{T}_{3}$ : Humic Acid $\left(1 \mathrm{~kg} \mathrm{ha}^{-1}\right)+$ Wheat straw $\left(10\right.$ tons ha $\left.{ }^{-1}\right)$

$\mathrm{T}_{4}$ : Humic Acid $\left(1 \mathrm{~kg} \mathrm{ha}^{-1}\right)+$ Mungbeans residue $\left(2.5\right.$ tons ha $\left.^{-1}\right)+$ Wheat straw $\left(5\right.$ tons ha $\left.^{-1}\right)$

$\mathrm{T}_{5}$ : Humic Acid $\left(1.5 \mathrm{~kg} \mathrm{ha}^{-1}\right)+$ Mungbeans residue $\left(5\right.$ tons ha $\left.^{-1}\right)$

$\mathrm{T}_{6}$ : Humic Acid $\left(1.5 \mathrm{~kg} \mathrm{ha}^{-1}\right)+$ Wheat straw $\left(10\right.$ tons ha $\left.^{-1}\right)$ 


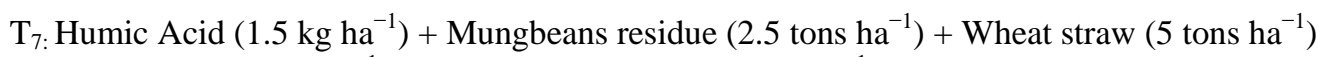

$\mathrm{T}_{8}$ : Humic Acid $\left(2 \mathrm{~kg} \mathrm{ha}^{-1}\right)+$ Mungbeans residue $\left(5\right.$ tons ha $\left.{ }^{-1}\right)$

$\mathrm{T}_{9}$ : Humic Acid $\left(2 \mathrm{~kg} \mathrm{ha}^{-1}\right)+$ Wheat straw $\left(10\right.$ tons ha $\left.^{-1}\right)$

$\mathrm{T}_{10}$ : Humic Acid $\left(2 \mathrm{~kg} \mathrm{ha}^{-1}\right)+$ Mungbeans residue $\left(2.5\right.$ tons ha $\left.^{-1}\right)+$ Wheat straw $\left(5\right.$ tons ha $\left.{ }^{-1}\right)$

$\mathrm{T}_{11}$ : Humic Acid $\left(2.5 \mathrm{~kg} \mathrm{ha}^{-1}\right)+$ Mungbeans residue $\left(5\right.$ tons ha $\left.^{-1}\right)$

$\mathrm{T}_{12}$ : Humic Acid $\left(2.5 \mathrm{~kg} \mathrm{ha}^{-1}\right)+$ Wheat straw $\left(10\right.$ tons ha $\left.^{-1}\right)$

$\mathrm{T}_{13}$ : Humic Acid $\left(2 \mathrm{~kg} \mathrm{ha}^{-1}\right)+$ Mungbeans residue $\left(2.5\right.$ tons ha $\left.^{-1}\right)+$ Wheat straw $\left(5\right.$ tons ha $\left.{ }^{-1}\right)$

\section{Procedures for Nitrogen Analysis}

Analysis of soil samples: Before sowing and after harvesting of wheat crop soil samples was analyzed for Nitrogen. Mineral nitrogen: $20 \mathrm{~g}$ soil sample was mixed with $100 \mathrm{ml}$ of $1 \mathrm{M} \mathrm{KCl}$ and put on end-to-end shaker for 1 hour. After filtration $20 \mathrm{ml}$ solution for each sample was purify with MgO devarda's alloy to recover $\mathrm{NH}_{4}{ }^{+}+$ $\mathrm{NO}_{3}{ }^{-}$concentration. Then $5 \mathrm{ml}$ boric acid was mixed as an indicator with samples and titrated against $0.005 \mathrm{M}$ $\mathrm{HCl}$.

$$
\begin{gathered}
\text { Mineral N }\left(\mathrm{mg} \mathrm{kg}^{-1}\right)=\frac{(\text { sample-blank }) \times 0.005 \times 0.014 \times 100 \times 10^{6}}{\text { Weight of soil } \times 20} \\
\text { Total N }\left(\mathrm{mg} \mathrm{kg}^{-1}\right)=\frac{(\text { sample-blank }) \times 0.005 \times 0.07 \times 100}{\text { Weight of soil } \times 1000}
\end{gathered}
$$

Analysis of plant samples: The plants samples were analyzed;

1) At pre-anthesis stage of wheat plants in leaves and stem

2) At maturity stage of wheat plants in leaves, stem and grain

The samples were washed with distilled water and after fully air drying at room temperature dried in oven at $60^{\circ} \mathrm{C}-70^{\circ} \mathrm{C}$ for 48 hours. The samples were grinded and stored.

Total nitrogen: Total nitrogen in plant samples was determined by Kjeldahl methods [11]. Plant sample of $0.2 \mathrm{~g}$ was digested with $3 \mathrm{ml}$ conc. $\mathrm{H}_{2} \mathrm{SO}_{4}$ in presence of $1.1 \mathrm{~g}$ digestion mixture $\left(\mathrm{K}_{2} \mathrm{SO}_{4}, \mathrm{CuSO}_{4}\right.$ and Se in 100:10:1 ratio). After cooling, then the samples were distilled with $20 \mathrm{ml} \mathrm{NaOH} \mathrm{(40 \% ).} \mathrm{Then} 5 \mathrm{ml}$ boric acid was mixed as an indicator with samples and titrated against $0.005 \mathrm{M} \mathrm{HCl}$.

Statistical Analysis: The data was statistically analyzed using analysis of variance techniques appropriate for randomized complete block design. Means was compared using LSD test at 0.05 level of probability, when the F-values was significant [12].

\section{Results}

\subsection{Soil Total Nitrogen ( $\mathrm{g} \mathrm{kg}^{-1}$ )}

Our experimental results showed that humic acid and crop residues have increased the soil nitrogen level (Table 1). Higher total nitrogen of (0.43) $\mathrm{g} \mathrm{kg}^{-1}$ was recorded from those plots where $2.5 \mathrm{~kg} \mathrm{ha}^{-1}$ of humic acid was used, whereas lower total $\mathrm{N}$ of (0.37) $\mathrm{g} \mathrm{kg}^{-1}$ in the plots in which $1 \mathrm{~kg} \mathrm{ha}^{-1}$ of humic acid was applied. Higher total $\mathrm{N}$ of (0.5) $\mathrm{g} \mathrm{kg}^{-1}$ was noted in the plots where 5 tons ha ${ }^{-1}$ of mungbean residues were incorporated, while lower nitrogen $(0.3) \mathrm{g} \mathrm{kg}^{-1}$ in the plots where 10 tons ha ${ }^{-1}$ of wheat straw incorporated The interactive effect of crop residues gives increasing trend line on humic acid levels.

\subsection{Soil Mineral Nitrogen ( $\mathrm{mg} \mathrm{kg}^{-1}$ )}

Statistical analysis of the data showed that mineral $\mathrm{N}$ content in soil was significantly $(\mathrm{P} \leq 0.05)$ affected by humic acid andcrop residues (Table 2). The results revealed that better mineral nitrogen content of (7.32) $\mathrm{mg}$ $\mathrm{kg}^{-1}$ was produced from those plots where $2.5 \mathrm{~kg} \mathrm{ha}^{-1}$ of humic acid as compared to $1 \mathrm{~kg} \mathrm{ha}^{-1}$ of humic acid which produced mineral $\mathrm{N}$ of (6.43) $\mathrm{mg} \mathrm{kg}^{-1}$. Higher mineral $\mathrm{N}$ of (7.4) $\mathrm{mg} \mathrm{kg}^{-1}$ was gain by incorporation of 5 tons $\mathrm{ha}^{-1}$ of mungbean residues similarly lower mineral nitrogen content of (6.4) $\mathrm{mg} \mathrm{kg}^{-1}$ was produced from those plots where 10 tons $\mathrm{ha}^{-1}$ of wheat straw was incorporated. Highest mineral nitrogen of (6.9) $\mathrm{mg} \mathrm{kg}^{-1} \mathrm{was}^{-1}$ produced from the rest of the treatments and lowest (6.0) $\mathrm{mg} \mathrm{kg}^{-1}$ was from control. 
Table 1. Soil analysis for total nitrogen $\left(\mathrm{g} \mathrm{kg}^{-1}\right)$ of wheat as affected by humic acid and crop residues application.

\begin{tabular}{|c|c|c|c|c|c|}
\hline \multirow{2}{*}{ Crop Residue (tons ha ${ }^{-1}$ ) } & \multicolumn{4}{|c|}{ Humic Acid $\left(\mathrm{kg} \mathrm{ha}^{-1}\right)$} & \multirow{2}{*}{ Mear } \\
\hline & 1 & 1.5 & 2 & 2.5 & \\
\hline 5 Mungbean & 0.4 & 0.5 & 0.5 & 0.5 & $0.5 \mathrm{a}$ \\
\hline 10 Wheat Straw & 0.3 & 0.3 & 0.3 & 0.4 & $0.3 \mathrm{c}$ \\
\hline 2.5 mungbean +5 wheat straw & 0.4 & 0.4 & 0.4 & 0.4 & $0.4 \mathrm{~b}$ \\
\hline Mean & $0.37 \mathrm{~d}$ & $0.40 \mathrm{c}$ & $0.42 \mathrm{~b}$ & $0.43 \mathrm{a}$ & \\
\hline Control & & & & & $0.2 \mathrm{~b}$ \\
\hline Rest of treatments & & & & & $0.4 \mathrm{a}$ \\
\hline
\end{tabular}

LSD value at $\mathrm{P} \leq 0.05$ for humic acid $=0.0$; LSD value at $\mathrm{P} \leq 0.05$ for crop residues $=0.0$; Humic acid and crop residues interaction $=$ Significant.

Table 2. Soil analysis for mineral nitrogen $\left(\mathrm{mg} \mathrm{kg}^{-1}\right)$ of wheat as affected by humic acid and crop residues application.

\begin{tabular}{|c|c|c|c|c|c|}
\hline \multirow{2}{*}{ Crop Residue (tons ha ${ }^{-1}$ ) } & \multicolumn{4}{|c|}{ Humic Acid $\left(\mathrm{kg} \mathrm{ha}^{-1}\right)$} & \multirow{2}{*}{ Mean } \\
\hline & 1 & 1.5 & 2 & 2.5 & \\
\hline 5 Mungbean & 6.9 & 7.1 & 7.6 & 8.1 & $7.4 \mathrm{a}$ \\
\hline 10 Wheat Straw & 6.1 & 6.2 & 6.4 & 6.9 & $6.4 \mathrm{c}$ \\
\hline 2.5 Mungbean +5 wheat straw & 6.3 & 6.8 & 6.9 & 7.0 & $6.8 \mathrm{~b}$ \\
\hline Mean & $6.43 \mathrm{~d}$ & $6.72 \mathrm{c}$ & $6.96 \mathrm{~b}$ & $7.32 \mathrm{a}$ & \\
\hline Control & & & & & $6.0 \mathrm{~b}$ \\
\hline Rest of treatments & & & & & $6.9 \mathrm{a}$ \\
\hline
\end{tabular}

LSD value at $\mathrm{P} \leq 0.05$ for humic acid $=0.0724$; $\mathrm{LSD}$ value at $\mathrm{P} \leq 0.05$ for crop residues $=0.0627$; Humic acid and crop residues interaction $=$ Significant.

Table 3. Stem nitrogen content of wheat at pre anthesis stage $\left(\mathrm{g} \mathrm{kg}^{-1}\right)$ as affected by humic acid and crop residues application.

\begin{tabular}{|c|c|c|c|c|c|}
\hline \multirow{2}{*}{ Crop Residue (tons ha ${ }^{-1}$ ) } & \multicolumn{4}{|c|}{ Humic Acid $\left(\mathrm{kg} \mathrm{ha}^{-1}\right)$} & \multirow{2}{*}{ Mean } \\
\hline & 1 & 1.5 & 2 & 2.5 & \\
\hline 5 Mungbean & 2.5 & 3.3 & 4.0 & 3.3 & $3.3 \mathrm{~b}$ \\
\hline 10 Wheat Straw & 2.2 & 2.6 & 3.7 & 3.0 & $2.9 \mathrm{c}$ \\
\hline 2.5 mungbean +5 wheat straw & 3.0 & 3.2 & 4.8 & 4.1 & $3.8 \mathrm{a}$ \\
\hline Mean & $2.5 \mathrm{~d}$ & $3.0 \mathrm{c}$ & $4.2 \mathrm{a}$ & $3.5 \mathrm{~b}$ & \\
\hline Control & & & & & $1.3 \mathrm{~b}$ \\
\hline Rest of treatments & & & & & $3.3 \mathrm{a}$ \\
\hline
\end{tabular}

LSD value at $\mathrm{P} \leq 0.05$ for humic acid $=0.11$; LSD value at $\mathrm{P} \leq 0.05$ for crop residues $=0.09$; Humic acid and crop residues interaction $=$ Significant.

\subsection{Stem Total Nitrogen at Pre Anthesis Stage ( $\left.\mathrm{g} \mathrm{kg}^{-1}\right)$}

Statistical analysis of the data showed that humic acid and crop residues significantly $(\mathrm{P} \leq 0.05)$ affected the total nitrogen level in wheat stem and increased from $1.3 \mathrm{~g} \mathrm{~kg}^{-1}$ to $3.3 \mathrm{~g} \mathrm{~kg}^{-1}$ (Table 3). Higher total nitrogen level (4.2) $\mathrm{g} \mathrm{kg}^{-1}$ was recorded in wheat stem in the plots, where $2 \mathrm{~kg} \mathrm{ha}^{-1}$ of humic acid was applied, while lower (2.5) $\mathrm{g} \mathrm{kg}^{-1}$ in $1 \mathrm{~kg} \mathrm{ha}^{-1}$ of humic acid plots. The plots in which mungbean and wheat straw (2.5 tons ha ${ }^{-1}$ and 5 tons $\mathrm{ha}^{-1}$ respectively) was incorporated, recorded higher nitrogen $\left(3.8 \mathrm{~g} \mathrm{~kg}^{-1}\right)$ in wheat stem, while lower $\left(2.9 \mathrm{~g} \mathrm{~kg}^{-1}\right)$ in wheat straw $\left(10\right.$ tons $\left.^{-1} \mathrm{~h}^{-1}\right)$. Crop residues gives us increasing trend line interactive effect on humic acid levels.

\subsection{Stem Total Nitrogen at Maturity Stage $\left(\mathrm{g} \mathrm{kg}^{-1}\right)$}

Stem total nitrogen at maturity was significantly $(\mathrm{P} \leq 0.05)$ affected by humic acid and crop residues (Table 4). Our experimental data showed that higher nitrogen $\left(2.3 \mathrm{~g} \mathrm{~kg}^{-1}\right)$ in wheat stem at maturity stage was recorded in the plots of $2.5 \mathrm{~kg} \mathrm{ha}^{-1}$ of humic acid and lower $\left(1.3 \mathrm{~g} \mathrm{~kg}^{-1}\right)$ in plots of $1 \mathrm{~kg} \mathrm{ha}^{-1}$ of humic acid. Further we have recorded higher total nitrogen $\left(2.1 \mathrm{~g} \mathrm{~kg}^{-1}\right)$ in wheat stem at maturity stage in the plots in which 5 tons ha ${ }^{-1}$ of 
mungbean incorporated, while lower nitrogen $\left(1.5 \mathrm{~g} \mathrm{~kg}^{-1}\right)$ was from the plots of 10 tons of wheat straw. The interaction effect of crop residues show increasing trend line on humic acid levels.

\subsection{Leaves Total Nitrogen at Pre Anthesis ( $\mathrm{g} \mathrm{kg}^{-1}$ )}

The humic acid and crop residues significantly $(\mathrm{P} \leq 0.05)$ affected stem total nitrogen (Table 5). Higher total nitrogen in leaves at pre anthesis stage of (5.2) $\mathrm{g} \mathrm{kg}^{-1}$ was recorded from plots where $2 \mathrm{~kg} \mathrm{ha}^{-1}$ of humic acid was applied, similarly lower nitrogen of (3.2) $\mathrm{g} \mathrm{kg}^{-1}$ was produced by applying of $1 \mathrm{~kg} \mathrm{ha}^{-1}$ of humic acid. We have reported higher nitrogen of (5.5) $\mathrm{g} \mathrm{kg}^{-1}$ in leaves when 5 tons ha $^{-1}$ of mungbean was incorporated whereas lower leaves nitrogen of (3.6) $\mathrm{g} \mathrm{kg}^{-1}$ was recorded in those plots where 10 tons ha ${ }^{-1}$ of wheat straw was incorporated. Crop residues gives us increasing trend line interactive effect on humic acid levels. Highest nitrogen value of (4.3) $\mathrm{g} \mathrm{kg}^{-1}$ was recorded from our treatments and lowest (1.9) $\mathrm{g} \mathrm{kg}^{-1}$ was from control.

\subsection{Leaves Nitrogen at Maturity Stage $\left(\mathrm{g} \mathrm{kg}^{-1}\right)$}

Statistical analysis of the data showed that humic acid and crop residues had a significant $(\mathrm{P} \leq 0.05)$ affect on leaves total nitrogen at maturity (Table 6). Mean value of humic acid indicated that higher total nitrogen of (4.6) $\mathrm{g} \mathrm{kg}^{-1}$ was observed in $2.5 \mathrm{~kg} \mathrm{ha}^{-1}$ of humic acid application and lower total nitrogen of (2.7) $\mathrm{g} \mathrm{kg}^{-1}$ was from $1 \mathrm{~kg} \mathrm{ha}^{-1}$ of humic acid. Higher total nitrogen of (4.2) $\mathrm{g} \mathrm{kg}^{-1}$ was recorded on incorporation of 5 tons ha ${ }^{-1}$ of mungbean and lower (3.2) $\mathrm{g} \mathrm{kg}^{-1}$ from 10 tons ha ${ }^{-1}$ of wheat straw. Highest nitrogen of (3.5) $\mathrm{g} \mathrm{kg}^{-1}$ was observed from the rest of the treatments and lowest (1.4) cm was from control.

\subsection{Grain total $\mathrm{N}\left(\mathrm{g} \mathrm{kg}^{-1}\right)$}

The effect of humic acid and crop residues application on grain total nitrogen is showed in Table 7. Statistical analysis of the data revealed that total nitrogen in grain of wheat was significantly $(\mathrm{P} \leq 0.05)$ affected by humic acid, crop residues, interaction and control vs. rest of the treatments. Mean values of the data showed that higher nitrogen in grain was (21.1) $\mathrm{g} \mathrm{kg}^{-1}$ when $2.5 \mathrm{~kg} \mathrm{ha}^{-1}$ of humic acid was applied, similarly lower nitrogen in grain was of (18.9) $\mathrm{g} \mathrm{kg}^{-1}$ recorded when $1 \mathrm{~kg} \mathrm{ha}^{-1}$ of humic acid was used whereas higher nitrogen (20.8) $\mathrm{g} \mathrm{kg}^{-1}$ were reported where 5 tons ha ${ }^{-1}$ of mungbean residues was incorporated while lower $\mathrm{N}$ of $(19.4) \mathrm{g} \mathrm{kg}^{-1}$ was from those plots where 10 tons ha ${ }^{-1}$ of wheat straw was incorporated. Highest nitrogen in grain was (20.0) $\mathrm{g} \mathrm{kg}^{-1} \mathrm{was}$

Table 4. Stem nitrogen content of wheat at maturity stage $\left(\mathrm{g} \mathrm{kg}^{-1}\right)$ as affected by humic acid and crop residues application.

\begin{tabular}{|c|c|c|c|c|c|c|}
\hline \multirow{2}{*}{\multicolumn{2}{|c|}{ Crop Residue (tons ha ${ }^{-1}$ ) }} & \multicolumn{4}{|c|}{ Humic Acid $\left(\mathrm{kg} \mathrm{ha}^{-1}\right)$} & \multirow{2}{*}{ Mean } \\
\hline & & 1 & 1.5 & 2 & 2.5 & \\
\hline \multirow{6}{*}{2.5} & 5 Mungbean & 1.6 & 1.8 & 2.1 & 2.8 & $2.1 \mathrm{a}$ \\
\hline & 10 Wheat Straw & 1.1 & 1.3 & 1.6 & 2.0 & $1.5 \mathrm{c}$ \\
\hline & mungbean +5 wheat straw & 1.3 & 1.4 & 1.8 & 2.2 & $1.7 \mathrm{~b}$ \\
\hline & Mean & $1.3 \mathrm{~d}$ & $1.5 \mathrm{c}$ & $1.8 \mathrm{~b}$ & $2.3 \mathrm{a}$ & \\
\hline & Control & & & & & $0.5 \mathrm{~b}$ \\
\hline & Rest of treatments & & & & & $1.7 \mathrm{a}$ \\
\hline
\end{tabular}

LSD value at $\mathrm{P} \leq 0.05$ for humic acid $=0.05$; LSD value at $\mathrm{P} \leq 0.05$ for crop residues $=0.04$; Humic acid and crop residues interaction $=$ Significant.

Table 5. Leaves nitrogen content of wheat at pre anthesis stage $\left(\mathrm{g} \mathrm{kg}^{-1}\right)$ as affected by humic acid and crop residues application.

\begin{tabular}{|c|c|c|c|c|c|}
\hline \multirow{2}{*}{ Crop Residue ( $\mathrm{t} \mathrm{ha}^{-1}$ ) } & \multicolumn{4}{|c|}{ Humic Acid $\left(\mathrm{kg} \mathrm{ha}^{-1}\right)$} & \multirow{2}{*}{ Mean } \\
\hline & 1 & 1.5 & 2 & 2.5 & \\
\hline 5 Mungbean & 4.3 & 5.3 & 6.9 & 5.4 & $5.5 \mathrm{a}$ \\
\hline 10 Wheat Straw & 2.5 & 3.7 & 4.3 & 3.9 & $3.6 \mathrm{c}$ \\
\hline 2.5 mungbean +5 wheat straw & 2.8 & 4.0 & 4.4 & 4.3 & $3.9 \mathrm{~b}$ \\
\hline Mean & $3.2 \mathrm{~d}$ & $4.3 \mathrm{c}$ & $5.2 \mathrm{a}$ & $4.6 \mathrm{~b}$ & \\
\hline Control & & & & & $1.9 \mathrm{~b}$ \\
\hline Rest of treatments & & & & & $4.3 \mathrm{a}$ \\
\hline
\end{tabular}

LSD value at $\mathrm{P} \leq 0.05$ for humic acid $=0.07$; LSD value at $\mathrm{P} \leq 0.05$ for crop residues $=0.06$; Humic acid and crop residues interaction $=$ Significant. 
Table 6. Leaves nitrogen content of wheat at maturity stage $\left(\mathrm{g} \mathrm{kg}^{-1}\right)$ as affected by humic acid and crop residues application.

\begin{tabular}{|c|c|c|c|c|c|}
\hline \multirow{2}{*}{ Crop Residue $\left(\mathrm{t} \mathrm{ha}^{-1}\right)$} & \multicolumn{4}{|c|}{ Humic Acid $\left(\mathrm{kg} \mathrm{ha}^{-1}\right)$} & \multirow{2}{*}{ Mean } \\
\hline & 1 & 1.5 & 2 & 2.5 & \\
\hline 5 Mungbean & 3.3 & 3.6 & 4.4 & 5.3 & $4.2 \mathrm{a}$ \\
\hline 10 Wheat Straw & 2.3 & 2.6 & 3.5 & 4.3 & $3.2 \mathrm{c}$ \\
\hline $2^{1 / 2}$ mungbean +5 wheat straw & 2.5 & 2.7 & 3.6 & 4.3 & $3.3 \mathrm{~b}$ \\
\hline Mean & $2.7 \mathrm{~d}$ & $3.0 \mathrm{c}$ & $3.9 \mathrm{~b}$ & $4.6 \mathrm{a}$ & \\
\hline Control & & & & & $1.4 \mathrm{~b}$ \\
\hline Rest of treatments & & & & & $3.5 \mathrm{a}$ \\
\hline
\end{tabular}

LSD value at $\mathrm{P} \leq 0.05$ for humic acid $=0.07$; LSD value at $\mathrm{P} \leq 0.05$ for crop residues $=0.07$; Humic acid and crop residues interaction $=$ Non- Significant.

Table 7. Grain nitrogen content of $\left(\mathrm{g} \mathrm{kg}^{-1}\right)$ of wheat as affected by humic acid and crop residues application.

\begin{tabular}{|c|c|c|c|c|c|}
\hline \multirow{2}{*}{ Crop Residue $\left(\mathrm{t} \mathrm{ha}^{-1}\right)$} & \multicolumn{4}{|c|}{ Humic Acid (kg ha $\left.{ }^{-1}\right)$} & \multirow{2}{*}{ Mean } \\
\hline & 1 & 1.5 & 2 & 2.5 & \\
\hline 5 Mungbean & 19.3 & 20.2 & 21.4 & 22.3 & $20.8 \mathrm{a}$ \\
\hline 10 Wheat Straw & 18.6 & 19.2 & 19.6 & 20.3 & $19.4 \mathrm{c}$ \\
\hline 2.5 mungbean +5 wheat straw & 18.8 & 19.8 & 20.3 & 20.7 & $19.9 \mathrm{~b}$ \\
\hline Mean & $18.9 \mathrm{~d}$ & $19.7 \mathrm{c}$ & $20.4 \mathrm{~b}$ & $21.1 \mathrm{a}$ & \\
\hline Control & & & & & $15.1 \mathrm{~b}$ \\
\hline Rest of treatments & & & & & $20.0 \mathrm{a}$ \\
\hline
\end{tabular}

LSD value at $\mathrm{P} \leq 0.05$ for humic acid $=0.23$; LSD value at $\mathrm{P} \leq 0.05$ for crop residues $=0.19$; Humic acid and crop residues interaction $=$ Significant.

from rest of the treatments and lowest (15.1) $\mathrm{g} \mathrm{kg}^{-1}$ was recorded from those plots which were controlled. The interaction effect of crop residues showed increasing trend line on humic acid levels.

\section{Discussion}

Humic acid (HA) is a natural product, improved the physicochemical and biological properties of the soils [8], and while crop residues are good sources of plant nutrients and are important components for the stability of agricultural ecosystems. We have recorded better total and mineral $\mathrm{N}$ on $2.5 \mathrm{~kg} \mathrm{ha}^{-1}$ of humic acid and 5 tons $\mathrm{ha}^{-1}$ of mungbean residues in the soil during our experiment. Our treatments significantly increased total and mineral Nin the soil as compared to control. High dose of humic acid increased the decomposition of legume residue to release more nitrogen. Humic acid contains although small amount of $\mathrm{N}$ but in a very suitable form [13] and serve as a catalyst in promoting the activity of microorganisms in soil Bhardwaj and Guar [14] and improve the physicochemical and biological environment of the soils [8] [15]. Higher nitrogen was recorded in wheat stem at pre anthesis stage in plots applied $2 \mathrm{~kg} \mathrm{ha}^{-1}$ of humic acid alone and $2.5 \mathrm{~kg} \mathrm{ha}^{-1}$ of humic acid combined with 2.5 tons ha ${ }^{-1}$ of mungbean +5 tons ha ${ }^{-1}$ wheat straw residues. Our treatments increased the accumulation of nitrogen in the wheat stem before start of anthesis as compared to control. Humic acid increase microbial activity, accumulation of nutrients [16] and decomposition of residues [17] which gives more $\mathrm{N}$ to the plots that is why treated plots wheat stem have more $\mathrm{N}$ than control. Leaves $\mathrm{N}$ content at pre anthesis stage showed better result on $2 \mathrm{~kg} \mathrm{ha}^{-1}$ of humic acid and lower on $1 \mathrm{~kg} \mathrm{ha}^{-1}$ of humic acid, similarly more $\mathrm{N}$ was observed from 5 tons ha ${ }^{-1}$ of mungbean residues as compared to 10 tons ha $^{-1}$ of wheat straw. Interaction and control vs. rest were also significant. Humic acid has potential to restore microbial activities in soils, increase availability of micronutrients by decomposition of residues and assimilation of $\mathrm{N}$ by plants to the legume incorporated plots as compared to sole plots [18]. About $25 \%$ of $\mathrm{N}$ and $\mathrm{P}, 50 \%$ of $\mathrm{S}$ and $75 \%$ of $\mathrm{K}$ taken up by cereal crops are retained in the crop residue, making them viable nutrient sources [19]. Stem, leaves and grain at maturity stage was significantly affected by humic acid, crop residues and control vs. rest. The interaction of leaves was non-significant while significant on stem and grain. Higher $\mathrm{N}$ content of stem, leaves and grain was reported by $2.5 \mathrm{~kg} \mathrm{ha}^{-1}$ of humic acid as compared to $1 \mathrm{~kg} \mathrm{ha}^{-1}$ of humic acid application. Agricultural crops were improved by adding 
water-soluble alkali metals salt of HA obtained from the alkali metal hydroxide treatment of an oxidized HA-containing ore and an effective amount of a plant nutrient composition including plant nutrients such as nitrogen [20]. Better results were obtained by incorporation of 5 tons ha ${ }^{-1}$ of mungbean as compared to 10 tons $\mathrm{ha}^{-1}$ of wheat straw. Mungbean residue incorporation had the advantage of producing protein-rich grain and was more useful for increasing the productivity of wheat [21].

\section{Conclusion}

It is concluded that the application of $2.5 \mathrm{~kg} \mathrm{ha}^{-1}$ of humic acid and 5 tons ha ${ }^{-1}$ of mungbean residues incorporation increased the soil and wheat plant nitrogen contents.

\section{References}

[1] MINFAL (2005) Agricultural statistics of Pakistan. Ministry of Food, Agriculture, Livestock, Economic Wing, Islamabad.

[2] Idris, M., Shah, S.M. and Mohammad, W. (2001) Integrated Use of Organic and Mineral Nitrogen, and Phosphorus on the Yield, Yield Components, N and P Uptake by Wheat. Pakistan Journal of Soil Science, 20, 77-80.

[3] Ahmad, N. (1999) Fertilizer Scenario in Pakistan Policies and Development. Agriculture and Fertilizer Use, National Fertilizer Development Centre (NFDC), Islamabad, 15-16.

[4] Tandon, H.L.S. (1998) Organic Fertilizer and Bio-Fertilizer-A Source Book. Fertilizer Development and Consultation Organization, New Delhi.

[5] Norse, D. (2003) Fertilizer and World Food Demand-Implication for Environmental Stresses. IFA-FAO Agriculture Conference "Global Food Security and the Role of Sustainable Fertilization”, International Fertilizer Industry Association (IFA), Rome.

[6] Hai, S.M. and Mir, S. (1998) The Lignitic Coal Derived HA and the Prospective Utilization in Pakistan Agriculture and Industry. Science Technology and Development, 17, 32-40.

[7] Sharif, M., Khattak, R.A. and Sarir, M.S. (2002) Wheat Yield and Nutrients Accumulation as Affected by Humic Acid and Chemical Fertilizers. Sarhad Journal of Agriculture, 18, 323-329.

[8] Khattak, R.A. and Muhammad, D. (2008) Increasing Crop Production through Humic Acid in Salt Affected Soils in Kohat Division (NWFP). Pak-Us Collaborative Research Endeavor, ALP Project, PARC, Islamabad.

[9] Bama, K.S., Selvakumari, G., Santhi, R. and Singaram, P. (2003) Effect of Humic Acid on Nutrient Release Pattern in an Alfisol (Typic haplustalf). Madras Agricultural Journal, 90, 665-670.

[10] Singh, Y. and Singh, B. (2001) Efficient Management of Primary Nutrients in the Rice-Wheat System. Journal of Crop Production, 4, 23-85. http://dx.doi.org/10.1300/J144v04n01_02

[11] Bremner, J.M. and Mulvaney, C.S. (1982) Nitrogen-Total. In: Page, A.L., Ed., Methods of Soil Analysis. Part 2. Chemical and Microbiological Properties, American Society of Agronomy, Soil Science Society of America, 595-624.

[12] Steel, R.G.D. and Torrie, J.H. (1980) Principles and Procedures of Statistics, a Biometrical Approach. McGraw-Hill Kogakusha, Ltd., Tokyo.

[13] Nisar, A. and Mir, S. (1989) Lignitic Coal Utilization in the Form of HA as Fertilizer and Soil Conditioner. Science Technology and Development, 8, 23-26.

[14] Bhardwaj, K.K. and Gaur, A. (1970) The Effect of HA on the Growth and Efficiency of N Fixation of Azotobacter ohroococum. Folia, 15, 367.

[15] Brannon, C.A. and Sommers, L.E. (1985) Preparation and Characterization of Model Humic Polymers Containing Organic Phosphorus. Soil Biology and Biochemistry, 17, 213-219. http://dx.doi.org/10.1016/0038-0717(85)90117-8

[16] Sarir, M.S., Sharif, M., Ahmed, Z. and Akhlaq, M. (2005) Influence of Different Levels of Humic Acid Application by Various Methods on the Yield and Yield Components of Maize. Sarhad Journal of Agriculture, 21, 75-81.

[17] Barron, P.F. and Wilson, M.A. (1981) Humic acid and coal structure study with Magic Angle Spinning 13 CCP-NMR. Nature, 9, 289-293.

[18] Jillani, G. and Ahmad, R. (1994) Substitution of Organic Manures with Humic Substances to Enhance Microbial Activity. National Congress on Soil Science NWFP, Agricultural University Peshawar, Pakistan.

[19] Singh, Y. (2003) Crop Residue Management in Rice-Wheat System. In: Addressing Resource Conservation Issues in Rice-Wheat Systems of South Asia. A Resource Book, Rice Wheat Consortium for Indo-Gangetic Plains-International Maize and Wheat Improvement Center, New Delhi, 153. 
[20] Alexander, W. (1991) Liquid Crop Stimulant. US Patent No. 5034045 A.

[21] Prasad, R., Singh, S. and Sharma, S.N. (1998) Interrelationships of Fertilizer Use and Other Agricultural Inputs for Higher Crop Yields. Fertilizer News, 43, 35-40. 